\title{
Identification of Bacterial Antigens in Circulating Immune Complexes of Infective Endocarditis
}

\author{
Robert D. Inman, Patricia B. Redecha, Stuart J. Knechtle, Eric S. Schned, \\ Ivo van de Rijn, and Charles L. Christian, Department of Medicine, \\ Hospital for Special Surgery, New York Hospital, Cornell University Medical \\ College, The Rockefeller University, New York 10021
}

\begin{abstract}
A B S TRACT The presence of circulating immune complexes (IC) in patients with infective endocarditis has been well documented but the contributions of host and bacterial components to these IC have not been defined. To study this question, IC were isolated from serum of a patient with Streptococcus faecalis endocarditis by differential polyethylene glycol precipitation and competitive binding to staphylococcal protein $\mathrm{A}$. A rabbit antiserum raised against the purified IC had reactivity by crossed immunoelectrophoresis primarily with an antigen derived from the cytoplasm of the infective organism. The antigen was a protein with a 12,000 -dalton molecular mass. In situ radiolabeling of the IC bound to the protein A demonstrated a component of the same molecular mass as the bacterial antigen recognized by the antiserum. The patient serum had multiple antibody specificities reactive with bacterial antigens, including the antigen recognized by the rabbit anti-IC antiserum. These techniques for isolation and characterization of circulating IC may have value in the study of IC diseases in which the inciting antigens are not known.
\end{abstract}

\section{INTRODUCTION}

Infective endocarditis (IE) ${ }^{1}$ is a clinical model for the study of the hyperimmune state in which the antigenic

Dr. van de Rijn is a recipient of an American Heart Association Established Investigator Award and a Irma T. Hirschl Career Scientist Award.

Received for publication 9 November 1981 and in revised form 26 March 1982.

${ }^{1}$ Abbreviations used in this paper: Az, azide; BSA, bovine serum albumin; CDM, chemically defined medium; IC, immune complexes; IE, infective endocarditis; LPO, lactoperoxidase; NHS, normal human serum; PBS, phosphate-buffered saline; PEG, polyethylene glycol; SDS-PAGE, sodium dodecyl sulfate-polyacrylamide gel electrophoresis; Staph A, Staphylococcus aureus; XIE, crossed immunoelectrophoresis. stimulus is known. Localization of IgG (1) and bacterial antigens (2) in glomeruli have implicated immune complexes (IC) in the pathogenesis of the glomerulonephritis associated with IE, but it has not been resolved whether such extracardiac manifestations of the disease derive from in situ formation or from deposition of circulating IC. Circulating IC have been documented in IE by several methods, using cryoprecipitation (3), polyethylene glycol (PEG) precipitation and Clq binding (4), and binding to Raji cells (5), but the relationship of the IC to exogenous vs. endogenous antigens of the host has not been clarified. Autoimmune reactants including antigammaglobulins (6-8) could be involved in IC formation, although no correlation was observed in one study between IC levels in patients with IE and the amount of rheumatoid factors measured by radioimmunoassay (9). Autoantibodies to other endogenous antigens (10) might also contribute to IC formation. The present study was undertaken to address the role of bacterial antigens in the formation of circulating IC in IE.

\section{METHODS}

Reagents and buffers. Rabbit IgG was obtained from Pentex Biochemical, Kankakee, IL. Polyethylene glycol (PEG, 6,000 mol wt; J. T. Baker Chemical Co., Phillipsburg, $\mathrm{NJ})$ was dissolved in borate saline buffer $(0.1 \mathrm{M}$ boric acid, $0.25 \mathrm{M}$ sodium tetraborate, $0.75 \mathrm{M} \mathrm{NaCl}, \mathrm{pH} 8.3$ ) at a $15 \%$ wt/vol stock solution and further diluted in the same buffer. EDTA buffer consisted of $0.2 \mathrm{M}$ disodium EDTA, adjusted to $\mathrm{pH} 7.5$ with $1 \mathrm{~N} \mathrm{NaOH}$. Phosphate-buffered saline with sodium azide (PBS-Az) was $0.01 \mathrm{M}$ phosphate, $0.15 \mathrm{M} \mathrm{NaCl}$, $0.1 \% \mathrm{Az}$, pH 7.2. Bovine serum albumin (BSA, Pentex Biochemical) was added to $\mathrm{PBS}-\mathrm{Az}$ at $0.5 \% \mathrm{wt} / \mathrm{vol}$ and the $\mathrm{pH}$ adjusted to 7.2-7.4 with $1 \mathrm{~N} \mathrm{NaOH}$. Pansorbin (CalbiochemBehring Corp., American Hoechst Corp., San Diego, CA) was used as a source of protein-A-bearing Staphylococcus aureus (Staph A). Trypsin was obtained from Sigma Chemical Co., St. Louis, MO and was combined with the selected substrate at a ratio of $1 \mathrm{mg}$ trypsin/100 $\mathrm{mg}$ substrate for a 48-h incubation at $37^{\circ} \mathrm{C}$. Sepharose-bound protein $A$ was obtained from Pharmacia Fine Chemicals, Piscataway, NJ. 


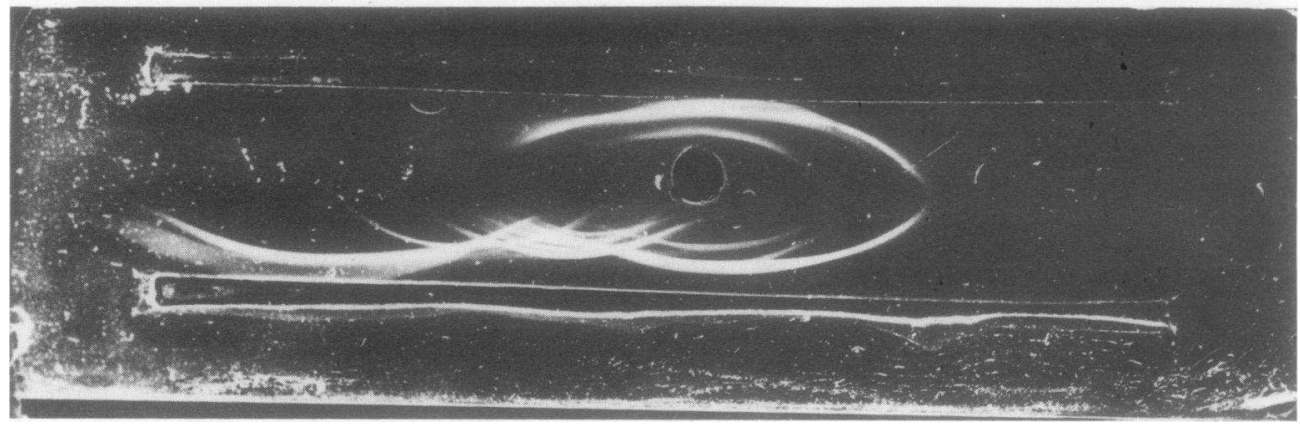

FIGURE 1 Immunoelectrophoresis assessing reactivity of rabbit anti-IC antiserum with NHS. Well contains NHS. Upper trough contains rabbit anti-NHS antiserum. Lower trough contains anti-IC antiserum. Anode is to the right.

Serum. Blood was allowed to clot at room temperature for 1-2 h. Serum was removed by centrifugation and stored at $-70^{\circ} \mathrm{C}$ in $0.4-\mathrm{ml}$ aliquots. Serum samples were thawed

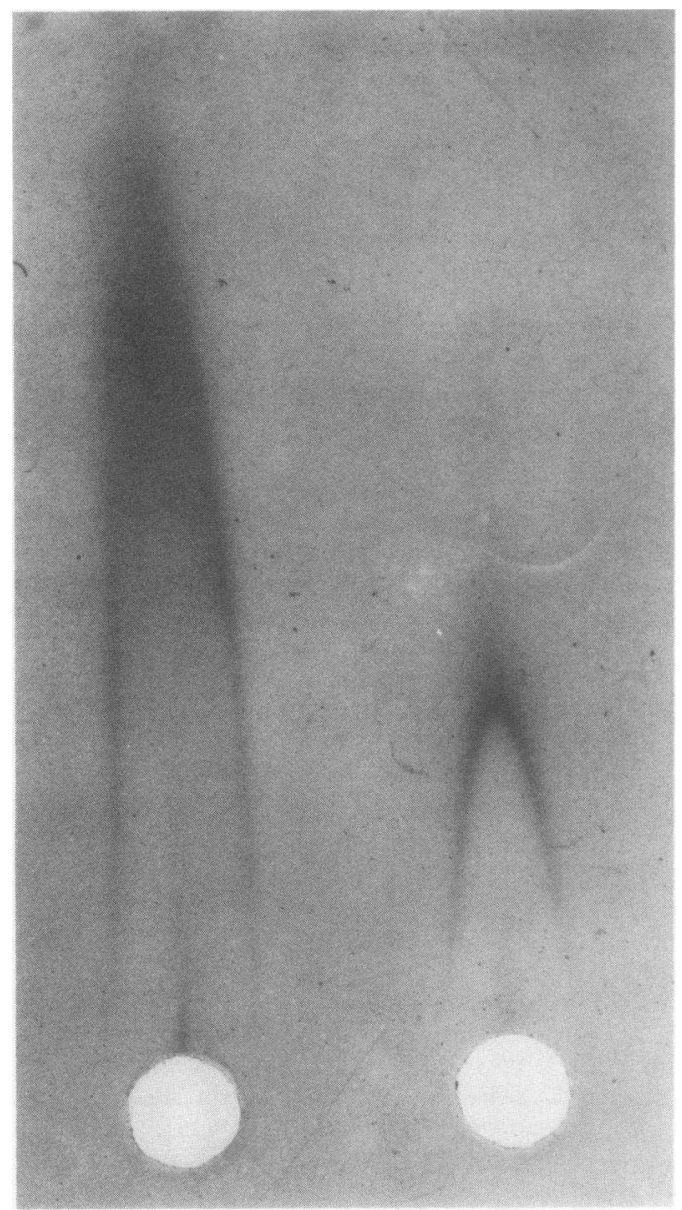

FIGURE 2 Rocket immunoelectrophoresis. Wells contain soluble preparation of $S$. faecalis cytoplasm, at concentrations of $0.66 \mathrm{mg} / \mathrm{ml}$ (left) and $0.16 \mathrm{mg} / \mathrm{ml}$. Gel contains $0.4 \mathrm{ml}$ of rabbit anti-IC antiserum. just before assay and used only once. Serial blood samples during the course of antibiotic therapy were obtained from a patient (H.S.) with IE (Streptococcus faecalis). The patient was selected for study because of high levels of circulating IC, as measured by the Staph A binding assay.

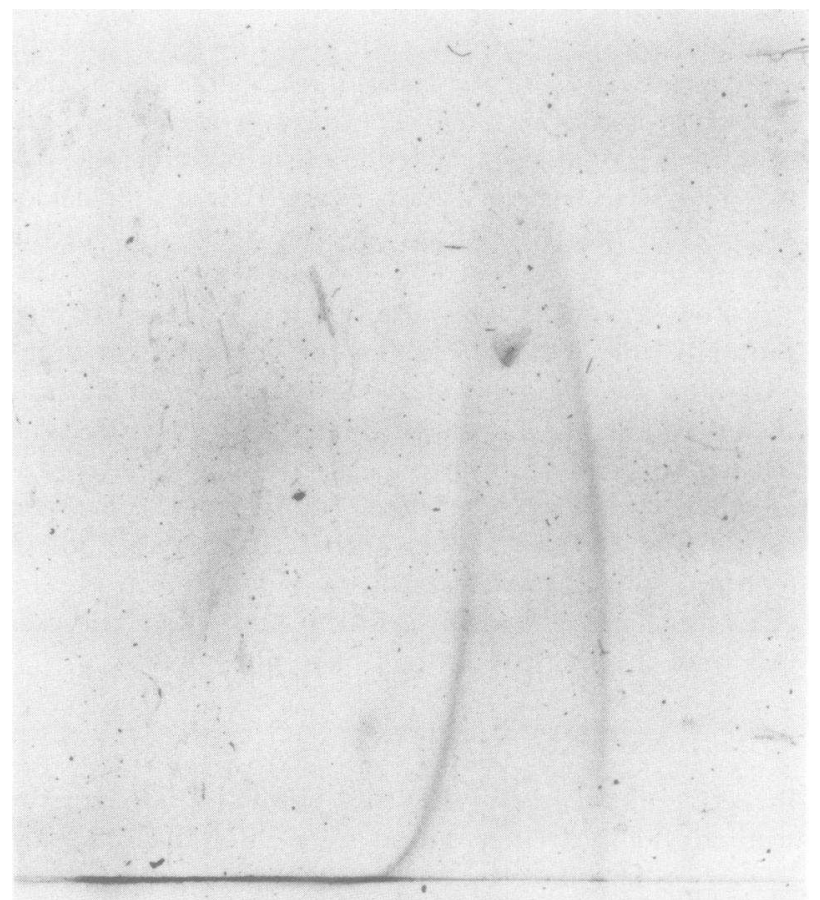

Figure 3 XIE. Well contains soluble preparation of $S$. faecalis cytoplasm, $5 \mathrm{mg} / \mathrm{ml}$. Gel for second dimension electrophoresis contains $0.4 \mathrm{ml}$ of rabbit anti-IC antiserum. 


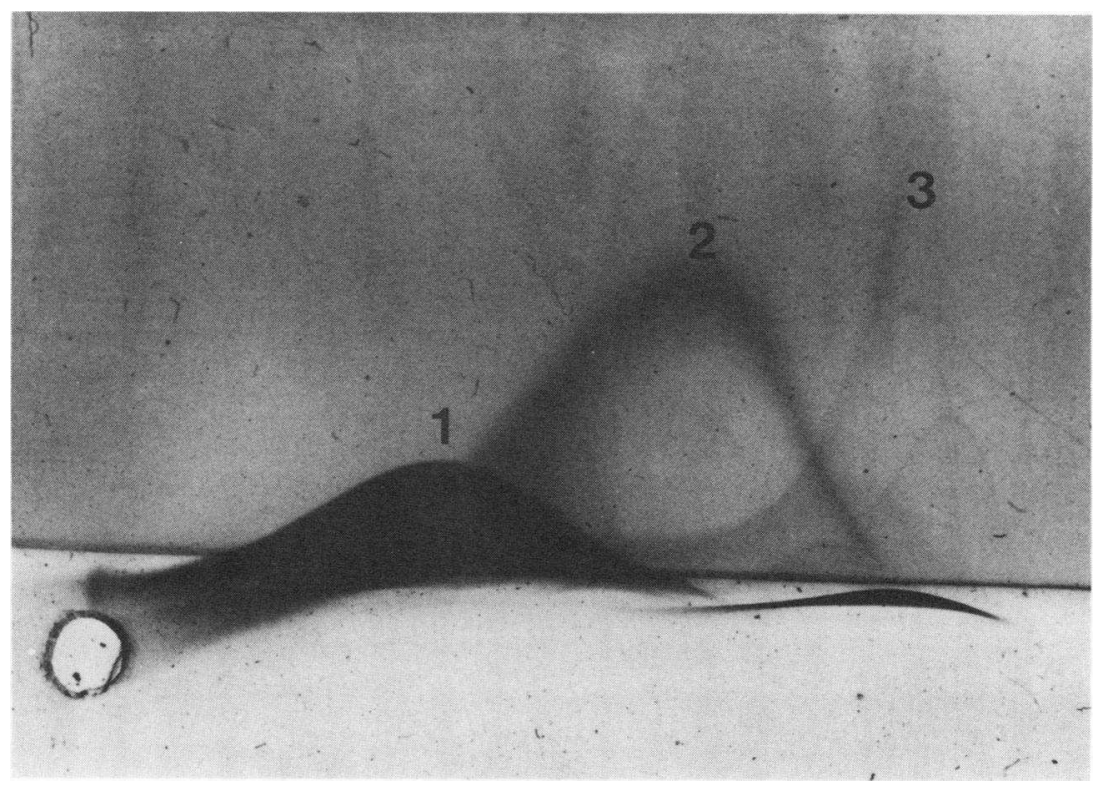

FIgURE 4 XIE. Well contains soluble preparation of $S$. faecalis cytoplasm, $5 \mathrm{mg} / \mathrm{ml}$. Gel for second dimension electrophoresis contains $0.4 \mathrm{ml}$ of serum from patient H.S., with $S$. faecalis endocarditis.

Isolation of IC. A modification of the Staph A binding assay (11) was used for isolation of IC. To $10 \times 75-\mathrm{mm}$ plastic tubes (Falcon Labware, Div. of Becton, Dickinson \& Co., Oxnard, CA) was added $300 \mu$ l EDTA buffer, $100 \mu \mathrm{l}$ of test serum, and $2.0 \mathrm{ml} 6 \%$ PEG. The tubes were incubated overnight at $4^{\circ} \mathrm{C}$ and centrifuged at $1,000 \mathrm{~g}$ for $20 \mathrm{~min}$. The supernate was aspirated and the pellet was resuspended in 5\% PGE, and centrifuged again. The supernate was aspirated, and the pellet was suspended in $200 \mu \mathrm{l}$ PBS-Az and allowed to sit at room temperature for $20 \mathrm{~min}$ with agitation to dissolve the precipitate. $100 \mu \mathrm{l}$ of the solubilized precipitate was transferred to a $10 \times 75-\mathrm{mm}$ tube that was prerinsed with PBS-BSA-Az and contained $100 \mu \mathrm{l}$ of a $0.8 \% \mathrm{vol} /$ vol suspension of Staph A in PBS-BSA-Az. After incubation in a $37^{\circ} \mathrm{C}$ water bath for $2 \mathrm{~h}, 1.0 \mathrm{ml}$ of PBS-BSA-Az was added and the tubes centrifuged at $1,000 \mathrm{~g}$ for $10 \mathrm{~min}$. The supernate was aspirated, and the pellet was resuspended in $1.0 \mathrm{ml}$ PBS-Az containing $5 \mathrm{mg} / \mathrm{ml}$ rabbit IgG. After another 2-h incubation at $37^{\circ} \mathrm{C}$ with frequent agitation, the tubes were centrifuged at $1,000 \mathrm{~g}$ for $20 \mathrm{~min}$. The Staph A pellets were washed two times by centrifugation with $2 \mathrm{ml}$ PBS-Az, then $200 \mu \mathrm{l}$ of either $3 \mathrm{M} \mathrm{NaSCN}$ or $1 \%$ sodium dodecyl sulfate (SDS) were added to the tubes. Previous studies showed comparable recovery of IC using these eluants (12). After incubation at $37^{\circ} \mathrm{C}$ for $30 \mathrm{~min}$ with frequent agitation, tubes were centrifuged at $1,000 \mathrm{~g}$ for $20 \mathrm{~min}$ and the supernate aspirated. The NaSCN eluates were dialyzed against PBS before use. The SDS eluates were used in SDS-polyacrylamide gel electrophoresis (SDS-PAGE) without further modification.

Immunization with IC. Preimmune sera were taken from rabbits before starting the immunization procedures. The material eluted from the Staph A with $3 \mathrm{M}$ NaSCN was emulsified with equal volumes of complete Freund's adjuvant. This was used for immunization of rabbits by subcutaneous inoculation using $0.4 \mathrm{ml}$ of immunogen per rabbit on each occasion. After the initial immunization, there were two booster injections 2 and 3 wk later. A control immunization used a $\mathrm{NaSCN}$ eluate from Staph A alone.

Surface radiolabeling of IC. The procedure outlined above for isolation of IC was carried out to completion of Staph A washing after incubation with rabbit IgG. PBS rather than PBS-Az, was used for washes to avoid interference with the radiolabeling procedure. The Staph A-bound IC were radiolabeled by the lactoperoxidase (LPO) method (13) as follows. To the tubes containing the washed Staph A pellets were added $20 \mu \mathrm{g}$ of LPO (Calbiochem-Behring Corp.), $250 \mu \mathrm{Ci}$ of $\mathrm{Na}^{125} \mathrm{I}$ (Amersham Corp., Arlington Heights, IL), and $10 \mu \mathrm{l}$ of $\mathrm{H}_{2} \mathrm{O}_{2}$. These were incubated with gentle agitation for $30 \mathrm{~min}$, then the reaction was stopped with $0.5 \mathrm{ml}$ PBS-Az. The radiolabeled IC were then eluted from the Staph A with either $3 \mathrm{M} \mathrm{NaSCN}$ or $1 \%$ SDS as described above. Control labeling of Staph A alone, without addition of serum or IgG, was performed concurrently.

Isolation and culturing of bacteria. S. faecalis isolated from the patient's blood was cultured on a blood agar plate. Colonies from the plate were removed with loops for inoculation of $250 \mathrm{ml}$ of Todd-Hewitt broth (Difco Laboratories, Detroit, MI), and incubated overnight at $37^{\circ} \mathrm{C}$. The culture was centrifuged at $1,000 \mathrm{~g}$ for $20 \mathrm{~min}$ and the supernatant aspirated. The pellet was resuspended in $5 \mathrm{ml}$ Todd-Hewitt broth and stored at $-70^{\circ} \mathrm{C}$ in $0.3-\mathrm{ml}$ lots. A $1 \%$ inoculation of bacteria from the frozen stock concentrate $(50 \mu \mathrm{l})$ was removed to inoculate $5 \mathrm{ml}$ of chemically defined medium (CDM), as developed by van de Rijn and Kessler (14). Growth of bacteria was monitored by optical density and when bacteria were in their log growth phase, $500 \mathrm{ml}$ of CDM was inoculated with the $5 \mathrm{ml}$ subculture. This was incubated overnight at $37^{\circ} \mathrm{C}$.

Fractionation of bacteria. . These methods have been described in detail previously $(15,16)$. Briefly, extracellular products were obtained by filtration of the CDM medium 


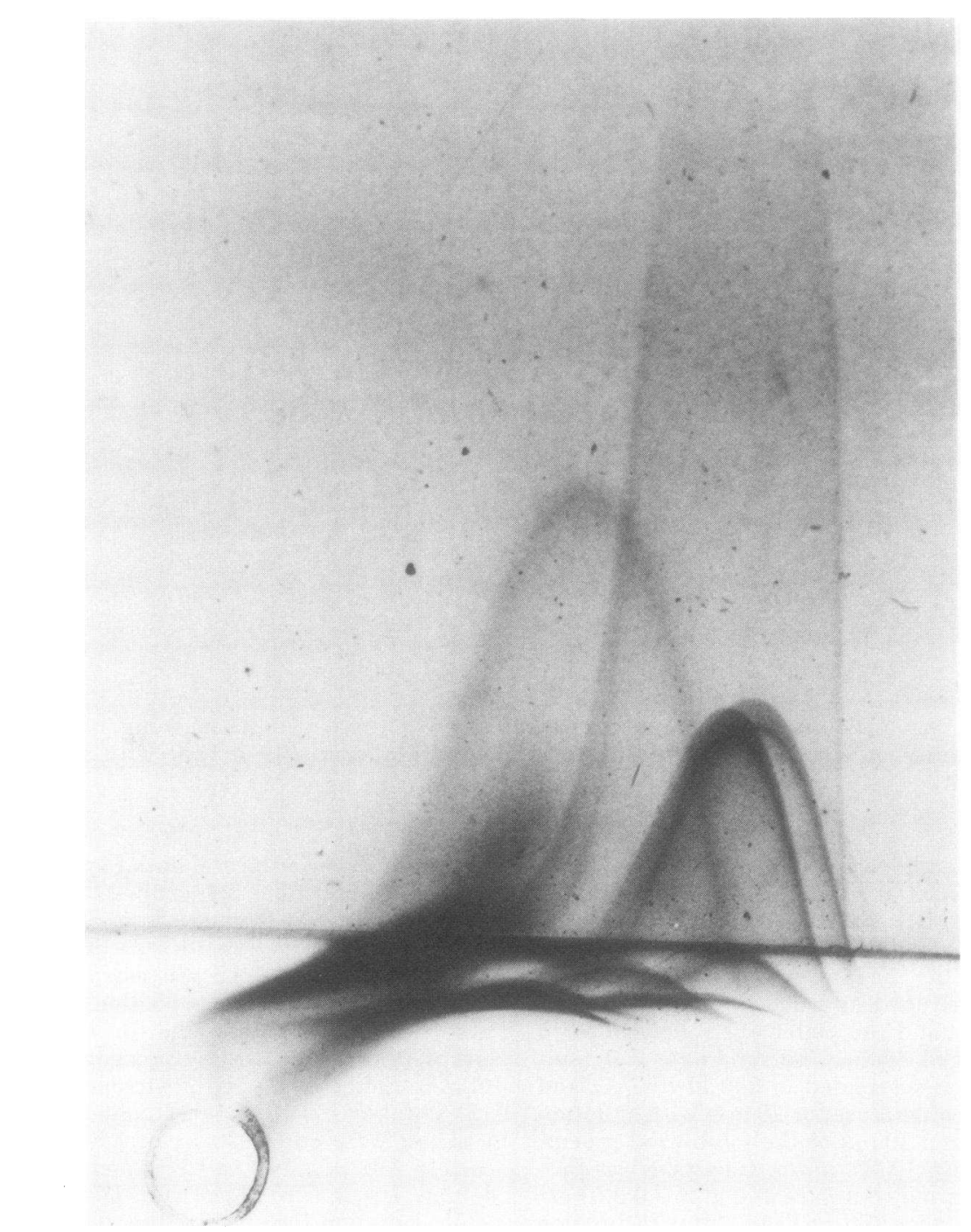

Figure 5 XIE. Well contains soluble preparation of $S$. faecalis cytoplasm, $5 \mathrm{mg} / \mathrm{ml}$. Gel for second dimension electrophoresis contains $0.4 \mathrm{ml}$ of serum from patient R.D. with $S$. faecalis endocarditis.

using an Amicon DM10 filter (Amicon Corp., Lexington, MA). Bacteria were broken by glass bead disintegration (15) in a vibrogen cell mill (Rho Scientific, Commack, NY). Differential centrifugations were then used to separate cell wall, cell membrane, and cytoplasm. For detergent extraction of cell wall and membrane, $10 \mathrm{mg}$ of material was added to $1 \mathrm{ml}$ of $4 \%$ Triton $\mathrm{X}-100$ (in $0.5 \mathrm{M}$ Tris- $\mathrm{HCl}, \mathrm{pH} 8.9$ ) and incubated at $37^{\circ} \mathrm{C}$ for $4 \mathrm{~h}$ with stirring. After centrifugation $(30,000 \mathrm{~g}$ for $10 \mathrm{~min})$ the supernatant was removed for analysis. Acid extraction of the cell wall was performed by adding $0.5 \mathrm{ml} 0.2 \mathrm{~N} \mathrm{HCl}$ to $10 \mathrm{mg}$ cell wall. This was placed in a boiling water bath for $5 \mathrm{~min}$, cooled on ice, and neutralized to $\mathrm{pH} 7.0$ with $1 \mathrm{~N} \mathrm{NaOH}$. After centrifugation $(1,000 \mathrm{~g}$ for $10 \mathrm{~min})$ the supernatant was removed for study. Immunological methods. Reactivity of rabbit antiserum was examined by double diffusion in agar plates and by immunoelectrophoresis. Rocket electrophoresis was performed as previously described (17). Crossed immunoelec- trophoresis (XIE) was performed on glass plates $(50 \times 50$ $\times 0.6 \mathrm{~mm}$ ) using $1 \%$ agarose gels prepared from Seakem HGT (Marine Colloids, Inc., Rockland, ME) $(18,19)$. Electrophoresis was carried out at $5 \mathrm{~V} / \mathrm{cm}$ for $60 \mathrm{~min}$ using a Pharmacia flat bed (Pharmacia Inc.) and a Lauda cooling system. After electrophoresis, an agarose strip $(10 \times 50 \mathrm{~mm})$ containing the separated antigens was retained on each plate while the rest of the gel was removed and replaced with $1 \%$ agarose containing either rabbit antiserum or patient serum. Electrophoresis was then carried out perpendicular to the original direction at $2 \mathrm{~V} / \mathrm{cm}$ for $16-20 \mathrm{~h}$. Gels were alternately pressed and washed three times with $0.1 \mathrm{M} \mathrm{NaCl}$. After a final press, they were briefly rinsed with a stream of distilled water and dried with a hair dryer before staining with Coomassie Brilliant Blue R-250.

Adsorption of antigen from bacterial cytoplasm. The IgG fraction of the rabbit antiserum was obtained by DEAE cellulose chromatography (DE-52, Whatman Ltd., Maid- 
stone, Kent, England). DE-52 and the antiserum were equilibrated with $0.02 \mathrm{M}$ phosphate buffer, $\mathrm{pH}$ 8.0. Material not retained on the column was made $0.15 \mathrm{M}$ in $\mathrm{NaCl}$. Rabbit IgG for control adsorption was obtained from Pentex Biochemical. The IgG preparations were coupled to cyanogen bromide-activated Sepharose 4B (20). A $66 \%$ vol/vol slurry $(0.3 \mathrm{ml})$ of each Sepharose preparation in PBS was incubated with $0.05 \mathrm{ml}$ of the cytoplasm preparation of $S$. faecalis. Adsorption was carried out at room temperature for $30 \mathrm{~min}$ followed by centrifugation at $1,000 \mathrm{~g}$ for $30 \mathrm{~min}$. The supernates were aspirated and run in XIE against the rabbit antiserum and against the patient's serum.

SDS-PAGE. Components were analyzed by SDS-PAGE by methods previously described (21). For these studies, IC were eluted from the Staph A by incubation with $1 \%$ SDS for $30 \mathrm{~min}$ at $30^{\circ} \mathrm{C}$. The eluate was combined with an equal volume of the following: $0.1 \mathrm{M}$ Tris, $0.0015 \mathrm{M}$ EDTA, $20 \%$ glycerol, $2 \%$ SDS, and $0.1 \mathrm{mg} / \mathrm{ml}$ bromphenol blue, $\mathrm{pH}$ 7.5. This mixture was placed in boiling water for $2 \mathrm{~min}$ then applied to either a 5 or $7.5 \%$ polyacrylamide gel. In certain cases $20 \mu \mathrm{l}$ of 2 -mercaptoethanol were combined with the eluate before SDS-PAGE. Electrophoresis was carried out at $100 \mathrm{~V}$ for $90 \mathrm{~min}$ in a buffer of $0.1 \mathrm{M}$ phosphate, $0.2 \%$ SDS, $\mathrm{pH}$ 7.2. The 10-cm gels were sliced into $1-\mathrm{mm}$ fractions in a Gilson gel slicer (Gilson Co., Inc., Worthington, $\mathrm{OH}$ ) and the fractions counted in a gamma counter. For molecular mass determination the following controls were electrophoresed concurrently: ribonuclease A ( 13,700 daltons), cytochrome $c(12,400$ daltons), chymotrypsinogen (25,000 daltons), and ovalbumin (45,000 daltons).

\section{RESULTS}

Rabbit antiserum reactivity with human serum. Ouchterlony double-diffusion analysis confirmed reac- tivity of the rabbit antiserum with normal human serum (NHS). Immunoelectrophoresis showed that this reactivity with NHS was confined almost exclusively to IgG (Fig. 1) with slight reactivity with IgM, as confirmed by lines of identity in Ouchterlony plates using IgG and IgM. The control rabbit immunized with the eluate from Staph A alone showed no reactivity with NHS.

Rabbit antiserum reactivity with bacterial components. Using Laurell rocket electrophoresis, the main reactivity of the antiserum was with the antigenic preparation derived from the bacterial cytoplasm (Fig. 2). Reactivity could be demonstrated with a $0.05 \mathrm{mg} /$ $\mathrm{ml}$ concentration of the cytoplasm. A lower degree of reactivity was present with the acid extract of the bacterial cell wall, with no precipitate seen at concentrations $<6.0 \mathrm{mg} / \mathrm{ml}$. There was no reactivity of the antiserum with the bacterial extracellular products, the detergent extract of the cell wall, nor with the bacterial membrane. Preimmune serum and antiserum from rabbits immunized with Staph A alone did not react with any streptococcal components.

XIE (Fig. 3) showed that there was a single antigen in the cytoplasmic preparation with which the antiserum reacted. The immunoprecipitate in XIE was eliminated by prior incubation of the antigen with trypsin. The single precipitate seen when the cytoplasm was electrophoresed into the rabbit antiserum was contrasted with the XIE pattern seen when the

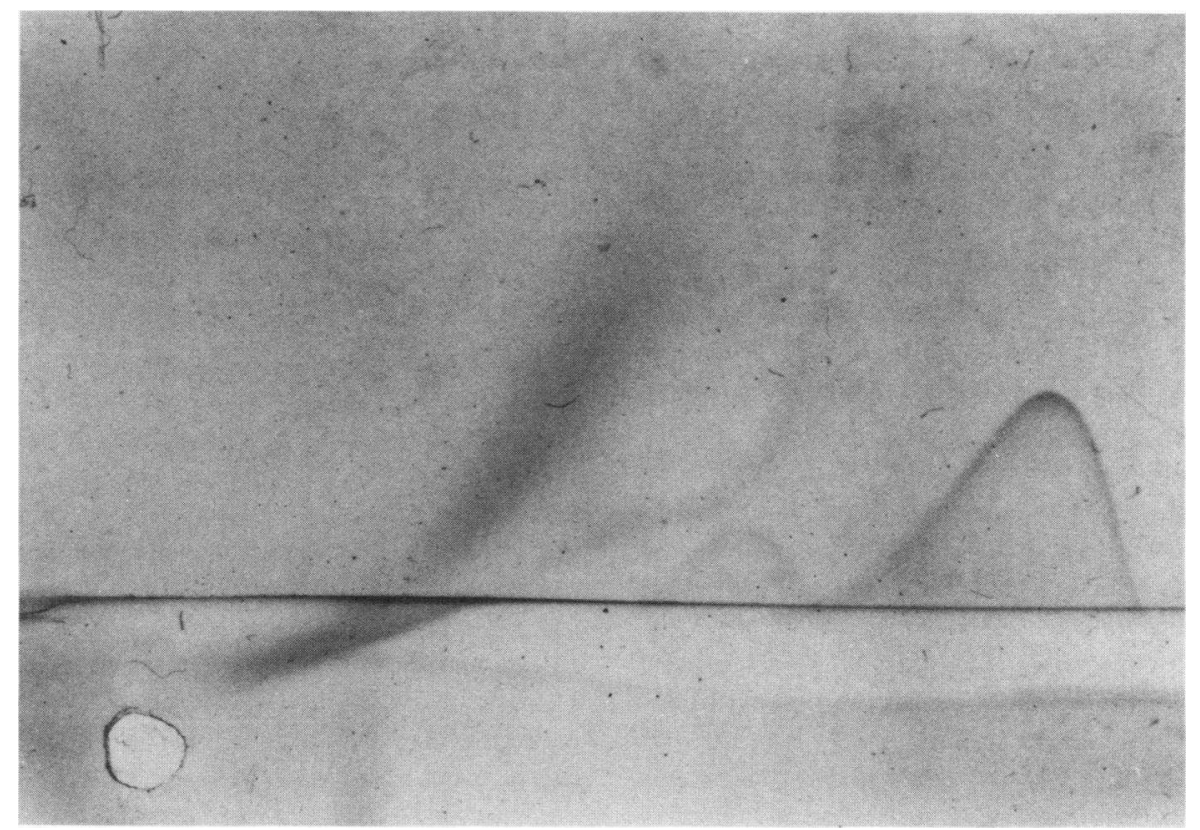

FIGURE 6 XIE. Well contains soluble preparation of $S$. faecalis cytoplasm, $5 \mathrm{mg} / \mathrm{ml}$. Gel for second dimension electrophoresis contains $0.4 \mathrm{ml}$ of serum from a patient with $S$. faecium endocarditis. 

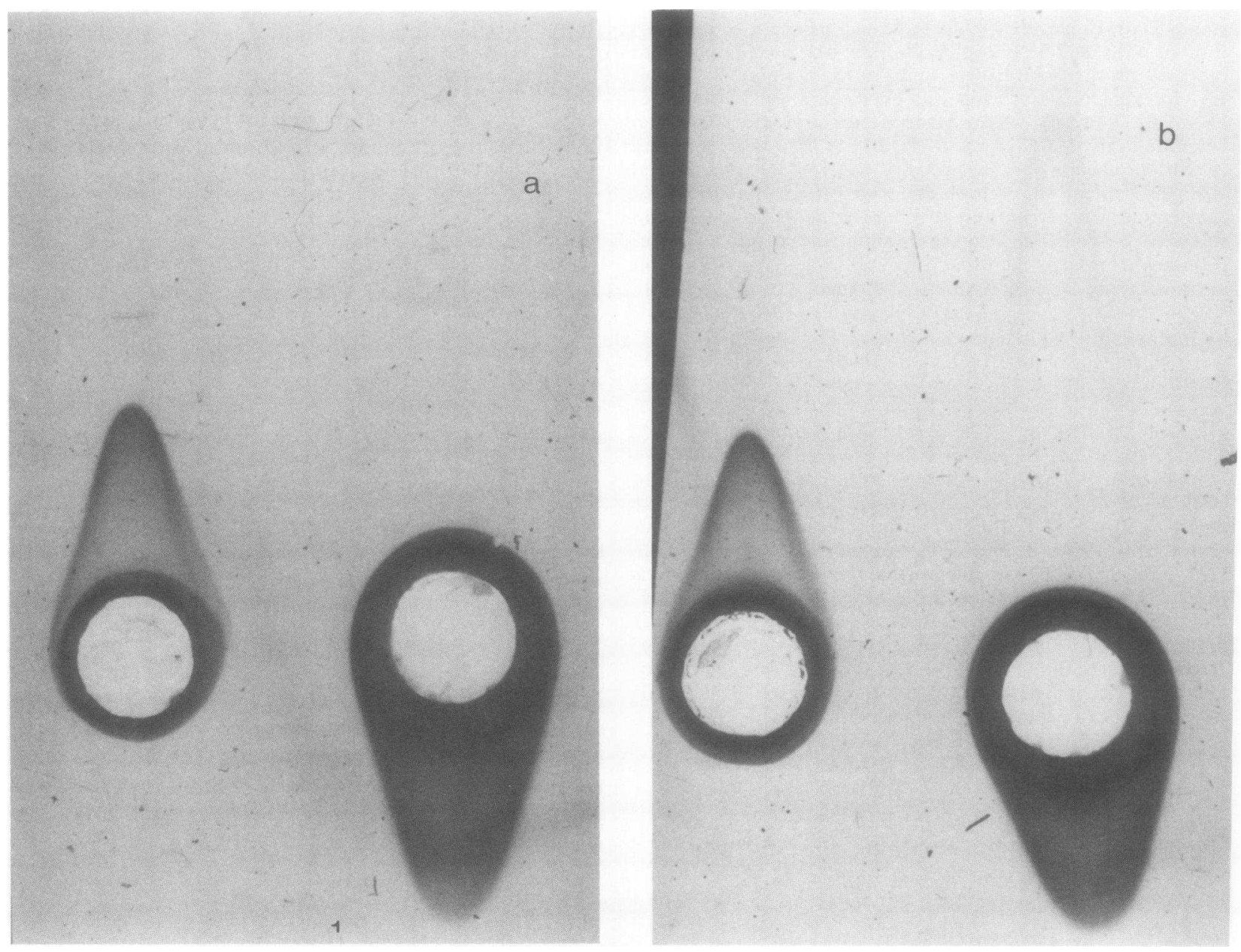

FIGURE 7 Rocket immunoelectrophoresis. (a) Precipitate (left well) and supernatant (right well) following addition of 5\% PEG to NHS. (b) Precipitate (left well) and supernatant (right well) after addition of 5\% PEG to NHS incubated with S. faecalis cytoplasm. (c) S. faecalis cytoplasm. In each case gel contains $0.4 \mu \mathrm{l}$ rabbit anti-IC antiserum.

cytoplasm reacted with the patient's serum under the same conditions (Fig. 4). In the latter there were several precipitates observed. For comparison, the cytoplasmic preparation was electrophoresed into the serum of another patient (R.D.) with $S$. faecalis IE (Fig. 5). This patient's serum also recognized several antigenic determinants in the cytoplasm of the bacterium, although the patterns appeared distinct from the first patient, both in electrophoretic mobility of the antigens and shape of the immunoprecipitates. Serum from a patient with Streptococcus faecium IE, a closely related group D streptococcus, also showed reactivity with the cytoplasm of $S$. faecalis, but with fewer specificities (Fig. 6). Sera from IE patients infected with the following organisms were all negative for reactivity with $S$. faecalis antigens: Streptococcus mitior, Streptococcus bovis, Staphylococcus aureus, Candida albicans.
PEG precipitation of antigen. To exclude the possibility that the rabbit was immunized with free, uncomplexed antigen derived from the patient's serum, a study using PEG precipitation was performed. Using the 5\% PEG for the isolation of the IC, it was demonstrated that the PEG precipitate of the purified bacterial cytoplasm did not show reactivity with the rabbit anti-IC antiserum, whereas the supernatant did. When the bacterial cytoplasm was incubated with NHS, then the PEG precipitation carried out, once again only the supernatant showed reactivity with the rabbit antiserum (Fig. 7). The presence of the antigen in the Staph A eluate used for immunization indicates that the antigen in the patient serum was precipitated by $5 \%$ PEG and suggests that it was bound specifically to immunoglobulin.

Molecular mass determination of bacterial cytoplasmic antigen. Exogenous radiolabeling of the cy- 


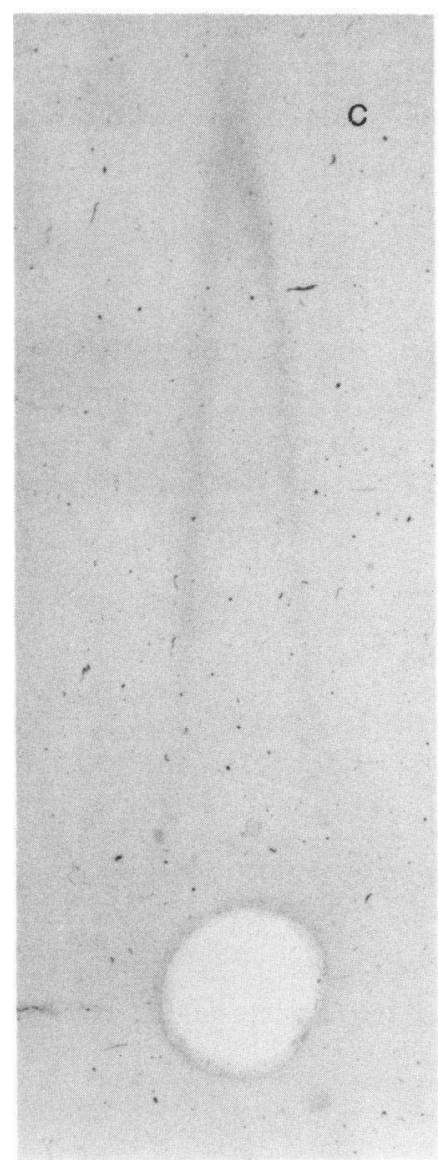

Figure 7 (Continued)

toplasmic preparation with ${ }^{125}$ I was performed by the LPO method. The preparation was electrophoresed in $\mathrm{XIE}$ using rabbit antiserum as described above. After pressing and staining, the immunoprecipitates were excised, placed in a test tube containing $200 \mu \mathrm{l} 1 \%$ SDS, $0.5 \mathrm{M} \mathrm{NaHCO}_{3}$, bromphenol blue, and glycerol. This was placed in boiling water for 2 min, then transferred to SDS-PAGE. Molecular mass was derived from comparison with known molecular mass markers electrophoresed in the same run under identical conditions. The main peak of activity indicated a component of 12,000 daltons, with a second peak at 24,000 daltons (Fig. 8). The absence of 2-mercaptoethanol in the SDS-PAGE resulted in no change in this two-peak pattern.

Surface labeling of Staph A-bound IC. Confirmation of the excised rocket analysis was sought by comparing these results with those obtained by in situ radiolabeling of the patient IC bound to the Staph A. Surface labeling of the Staph A-bound IC (Fig. 9) illustraies on SDS-PAGE a 12,000-dalton component. The presence of a 24,000-dalton peak could not be assessed because this component is obscured by the $\mathrm{L}$

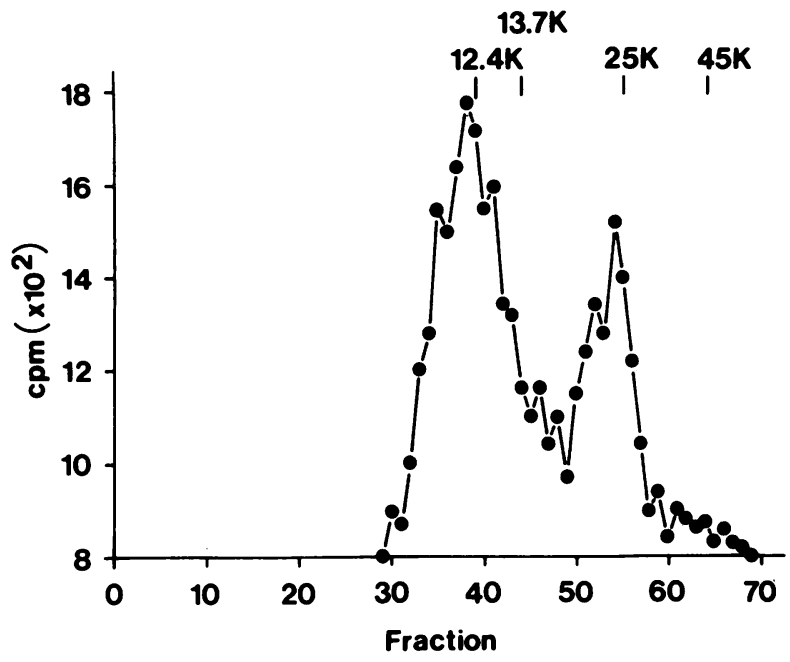

Figure 8 7.5\% SDS. PAGE (with $20 \mu$ l 2-mercaptoethanol) of excised immunoprecipitate derived from XIE of radiolabeled $S$. faecalis cytoplasm electrophoresed into agar containing rabbit anti-IC antiserum. Top of gel to the right. Peaks correspond to molecular mass of 12,000 and 24,000 daltons.

chain of IgG peak, which is labeled and eluted concomitantly with the antigen. Control labeling experiments of Staph A alone (Fig. 10a) and Sepharose-protein A (Fig. 10b) indicated that the labeling and elution procedures yielded protein A from the staphylococcal surface as a predictable background phenomenon. The recombination of dissociated components of the surface labeled IC proved difficult to demonstrate defin-

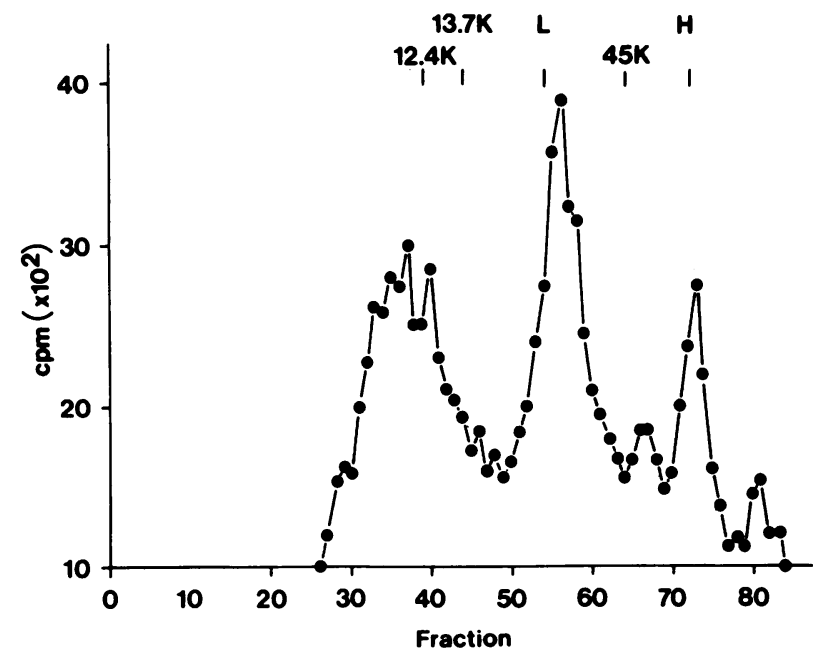

Figure 9 7.5\% SDS. PAGE (with $20 \mu$ l 2-mercaptoethanol) of patient IC radiolabeled in situ on surface of Staph A labeled IC eluted with 2\% SDS (Methods). Top of gel to the right. Major peaks correspond to molecular mass of 12,000 , 24,000 , and 51,000 daltons. $H$ and $L$ designate positions of heavy and light chains of IgG electrophoresed under the same conditions. 

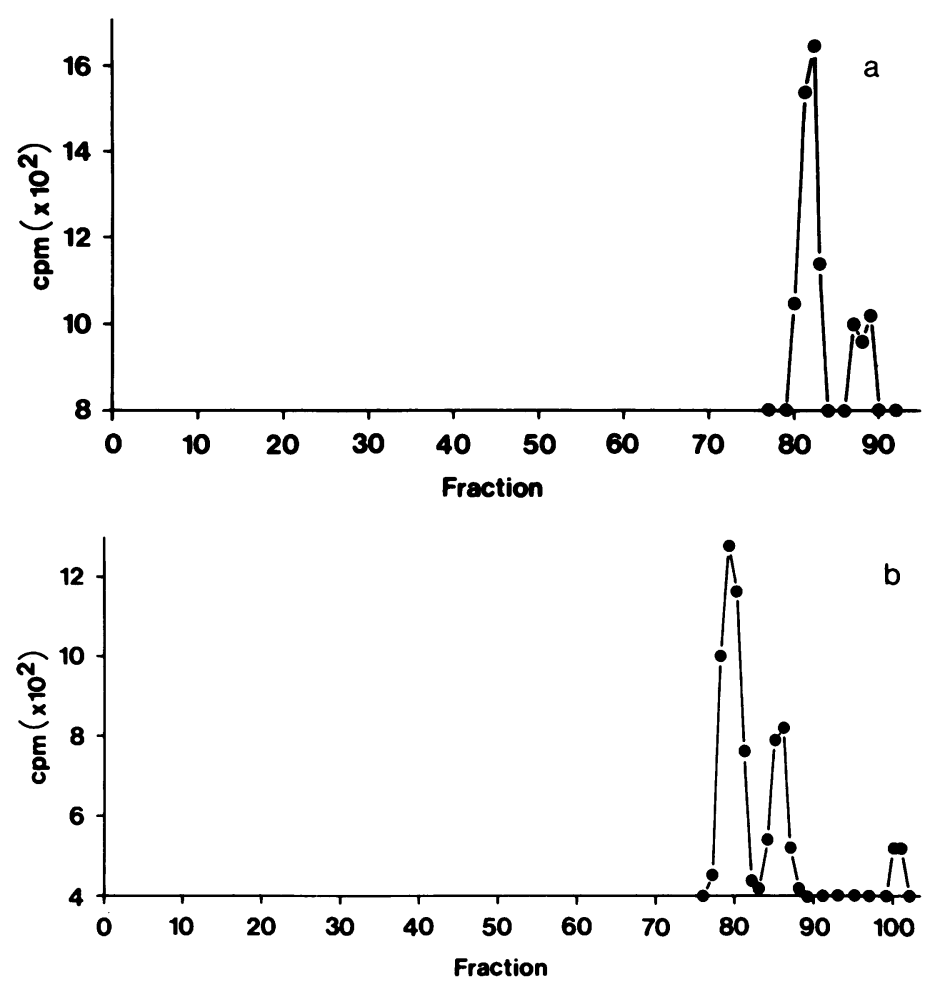

Figure 10 7.5\% SDS. PAGE (with $20 \mu$ l 2-mercaptoethanol). (a) Surface labeling of Staph A by LPO method, with subsequent elution by $2 \%$ SDS. (b) Surface labeling of Sepharose-protein A LPO method, with elution by $2 \%$ SDS.

itively. The cycle of elution, dissociation and reassociation of antigen and antibody moieties might result in denaturing effects on each component. The identity of the 12,000-dalton component defined by the antiIC antiserum reacting with bacterial products (Fig. 8) and the 12,000-dalton component defined by surfacelabeling of IC (Fig. 9) remains presumptive only.

\section{DISCUSSION}

It has remained a controversial issue whether the pathogenesis of the extracardiac manifestations of IE results primarily from septic microemboli or circulating IC. The observations of hypocomplementemia and glomerular deposits of IgG and complement (1) by immunofluorescence provided indirect support for the latter. Although immunoglobulins eluted from glomeruli have been shown to have reactivity with bacteria (22), recent studies in experimental IE have continued to implicate septic emboli as the initiating event in renal inflammation (23). Several reports have now documented circulating IC in patients with IE. Serum cryoglobulins were found in 19 of 20 patients with IE, and the concentration of the cryoglobulins tended to fall with therapy and clinical improvement of the pa- tients (3). Using a PEG precipitation assay and the Clq binding assay, circulating IC were found in $84 \%$ of patients with IE (4). Bayer et al. (5) found elevated serum levels of IC by the Raji cell assay and noted a positive correlation of IC levels with duration of illness, extravalvular manifestations of IE, and hypocomplementemia. Whether the antigens in these circulating IC are of microbial or host origin is unresolved. A previous study on PEG precipitates in IE failed to demonstrate bacterial antigen or host antibody directed against bacteria (24), although some investigators have found evidence implicating bacterial antigens during the course of Staph A bacteriemia (25). Our recent studies using binding to Staph A for characterization of IC in patients with hepatitis B systemic vasculitis (12) led us to further develop this methodology for the study of IC in patients with IE.

A patient with IE due to $S$. faecalis was found to have increased levels of circulating IC by the Staph $A$ binding assay. By the use of PEG precipitation and binding to Staph A to isolate the IC from the patient's serum, we raised an antibody in rabbits against the IC. Successful immunization of the rabbit by the immunoglobulin moiety of the IC was confirmed by immunoelectrophoresis. To search for bacterial antigens 
within the IC, S. faecalis isolated from the patient's blood was cultured and fractionated into constituent parts. The organism was cultured in a CDM so that the reactivity with bacterial antigens could be assessed in conditions free of contamination by serum. XIE indicated that the predominant reactivity of the rabbit antiserum was against a protein derived from the bacterial cytoplasm. The molecular mass of this component, as measured by SDS-PAGE, was 12,000 daltons. A component of 24,000 daltons was also observed on SDS-PAGE, suggesting the possibility of a dimeric form of the lower molecular mass component or a second antigen.

The possibility that the rabbit had been immunized with free antigen from patient serum was minimized by the finding that the antigen either alone or when incubated with NHS was not precipitable in the 5\% PEG used for isolation of the IC. The finding of a small amount of reactivity of the rabbit antiserum with a bacterial cell wall component indicated that the circulating IC in the patient's serum likely were heterogeneous, containing at least two different antigenantibody systems. The possibility exists that immunization of additional animals might have revealed additional bacterial products contributing to IC formation. The persistence of IC for a prolonged period after the patient's blood cultures became sterile and the sustained immune response to bacterial antigens suggests that some of the delayed manifestations of IE may be secondary to the host immune response to soluble products of bacteria rather than peripheral deposition of viable organisms.

Although the patient had demonstrable antibodies against several bacterial antigens, the IC studied suggested that only a select few of these antigen-antibody systems were represented in the population of circulating IC. It may be that the other antigen-antibody systems in the patient serum were not represented in our analyzed IC because the IC of these alternative specificities were rapidly cleared from the patient's circulation by the monocyte-macrophage system. Alternatively, the sampling of blood may have occurred at a time of marked antibody excess, when these antigens were present only in trace amounts. It is also possible that the two antigens detected were more immunogenic than the others. Even with the same infecting organism the patterns of antibodies elicited by different patients can be quite dissimilar, as was observed in the XIE pattern of two patients' serum against the cytoplasm of $S$. faecalis. The value of the rabbit antiserum in these analyses was as an immunospecific probe with reactivity restricted to those antigens involved in IC formation, in contradistinction to the patient serum that revealed multiple reactivities against a variety of antigens. The observation that multiple immunoreactivities of patients' sera, as detected by XIE, were sustained for a prolonged period after institution of antimicrobial therapy implies a continuing immunogenic stimulus by bacterial antigens that could be involved in IC-mediated injury at varied levels and at different stages of disease.

In two clinical models of IC disease where etiological factors are known (hepatitis B virus-related vasculitis and IE) the techniques herein described have demonstrated microbial antigens in purified IC. On the basis of this experience, comparable methods of study may lead to the identification and characterization of antigens involved in IC formation in diseases of unknown etiology.

\section{ACKNOWLEDGMENTS}

Gratitude is expressed to Mrs. Hjordis Kerezman for secretarial assistance.

This work was supported by National Institutes of Health grants AM 14627 and HL 27766.

\section{REFERENCES}

1. Gutman, R. A., G. E. Striker, B. C. Gilliland, and R. E. Cutler. 1972. The immune complex glomerulonephritis of bacterial endocarditis. Medicine (Baltimore). 51: 125.

2. Yum, M. N., L. J. Wheat, D. Maxwell, and J. L. Edwards. 1978. Immunofluorescent localization of Staphylococcus aureus antigen in acute bacterial endocarditis nephritis. Am. J. Clin. Pathol. 70: 832-835.

3. Hurwitz, D., F. P. Quismorio, and G. J. Friou. 1975. Cryoglobulinemia in patients with infectious endocarditis. Clin. Exp. Immunol. 19: 131-141.

4. Cabane, J., P. Godeau, G. Herreman, J. Acar, M. Digeon, and J. Bach. 1979. Fate of circulating immune complexes in infective endocarditis. Am. J. Med. 66: 277282.

5. Bayer, A. S., A. N. Theofilopoulos, R. Eisenberg, F. J. Dixon, and L. B. Guze. 1976. Circulating immune complexes in infective endocarditis. N. Engl. J. Med. 295: 1500-1505.

6. Abruzzo, J. L., and C. L. Christian. 1961. The induction of a rheumatoid factor-like substance in rabbits. J. Exp. Med. 114: 791-806.

7. Williams, R. C., and H. G. Kunkel. 1962. Rheumatoid factor, complement, and conglutinin aberrations in patients with subacute bacterial endocarditis. J. Clin. Invest. 41: 666-675.

8. Messner, R. P., T. Laxdal, P. G. Quie, and R. C. Williams. 1968. Rheumatoid factors in subacute bacterial endocarditis-bacterium, duration of disease, or genetic predisposition. Ann. Intern. Med. 68: 746-756.

9. Carson, D. A., A. S. Bayer, R. A. Eisenberg, S. Lawrance, and A. Theofilopoulos. 1978. IgG rheumatoid factor in subacute bacterial endocarditis: relationship to IgM rheumatoid factor and circulating immune complexes. Clin. Exp. Immunol. 31: 100-103.

10. Bacon, P. A., C. Davidson, and B. Smith. 1974. Antibodies to Candida and autoantibodies in subacute endocarditis. Q. J. Med. 43: 537-550. 
11. McDougal, J. S., P. B. Redecha, R. D. Inman, and C. L. Christian. 1979. Binding of immunoglobulin $G$ aggregates and immune complexes in human sera to Staphylococci containing protein A. J. Clin. Invest. 63: 627636.

12. Inman, R. D., J. S. McDougal, P. B. Redecha, M. D. Lockshin, C. E. Stevens, and C. L. Christian. 1981. Isolation and characterization of circulating immune complexes in patients with hepatitis B systemic vasculitis. Clin. Immunol. Immunopathol. 21: 364-374.

13. Marchalonis, J. J. 1969. An enzymatic method for the trace iodination of immunoglobulins and other proteins. Biochem. J. 113: 299-305.

14. van de Rijn, I., and R. E. Kessler. 1980. Growth characteristics of group A streptococci in a new chemically defined medium. Infect. Immun. 27: 444-448.

15. van de Rijn, I., J. B. Zabriskie, and M. McCarty. 1977. Group A streptococcal antigens cross-reactive with myocardium. Purification of heart-reactive antibody and isolation and characterization of the streptococcal antigen. J. Exp. Med. 146: 579-599.

16. Villarreal, H., V. A. Fischetti, I. van de Rijn, and J. B. Zabriskie. 1979. The occurrence of a protein in the extracellular products of streptococci isolated from patients with acute glomerulonephritis. J. Exp. Med. 149: 459-472.

17. Week, B. 1973. Rocket immunoelectrophoresis. Scand. J. Immunol. 2(Suppl. 1): 37-46.
18. Laurell, C. B. 1965. Antigen-antibody crossed electrophoresis. Anal. Biochem. 10: 358-361.

19. Weeke, B. 1973. Crossed immunoelectrophoresis. 1973. Scand. J. Immunol. 2(Suppl. 1): 47-56.

20. Porath, J. R., R. Axen, and S. Ermback. 1967. Chemical coupling of proteins to agar. Nature (Lond.). 215: 14911492.

21. Weber, K., and M. Osborn. 1969. The reliability of molecular weight determinations by dodecyl sulfate-polyacrylamide gel electrophoresis. J. Biol. Chem. 244: 4406-4412.

22. Levy, R. L., and R. Hong. 1973. The immune nature of subacute bacterial endocarditis (SBE) nephritis. Am. J. Med. 54: 645-652.

23. Thorig, L., M. R. Daha, F. Eulderink, W. C. KooyBauer, and J. Thompson. 1980. Experimental Streptococcus sauguis endocarditis: immune complexes and renal involvement. Clin. Exp. Immunol. 40: 469-477.

24. Burton-Kee, J., P. Morgan-Capner, and J. F. Mowbray. 1980. Nature of circulating immune complexes in infective endocarditis. J. Clin. Invest. 33: 653-659.

25. Tabbarah, Z. A., J. L. Wheat, R. B. Kohler, and $\mathbf{H}$ White. 1980. Thermodissociation of staphylococcal immune complexes and detection of staphylococcal antigen in serum from patients with Staphylococcus aureus bacteremia. J. Clin. Microbiol. 11: 703-709. 